\title{
FUTEBOL MASCULINO NOS JOGOS OLÍMPICOS DE LONDRES/2012: ENQUADRAMENTOS DE ALGUNS TELEJORNAIS BRASILEIROS
}

\author{
MEN'S SOCCER TEAM IN THE 2012 LONDON OLYMPICS: FRAMING OF TELEVISION \\ JOURNALISM IN BRAZIL
}

FÚTBOL MASCULINO EN LOS JUEGOS OLÍMPICOS DE LONDRES/2012: ENCUADRES DEL PERIODISMO TELEVISIVO EN BRASIL

\author{
Antonio Luis Fermino ${ }^{1}$ \\ Leandro Bianchini ${ }^{2}$ \\ Heitor Luiz Furtado ${ }^{3}$ \\ Josimar Lottermann ${ }^{4}$ \\ Giovani De Lorenzi Pires 5
}

Resumo

\begin{abstract}
Este artigo surge de uma pesquisa que teve por objetivo analisar os telejornais da Record (JR), da Band (JB) e Nacional (JN - Globo), comparando os enquadramentos dos seus discursos jornalísticos na cobertura do torneio de futebol masculino por ocasião dos Jogos Olímpicos de Londres em 2012. A base teórico-metodológica do estudo foi a teoria do enquadramento (frame analysis), fundamentada na teoria do espelho do interacionismo simbólico de Evrving Goffman e em uma releitura, para o jornalismo, realizada por Tuckman. A pesquisa teve como resultado a identificação de cinco categorias que se desenvolvem neste artigo: a) Os direitos televisivos e cobertura jornalística; b) 0 não agendamento; c) 0 nacionalismo; d) A personificação e d) 0 infoentretenimento. A análise conclui que os telejornais evidenciam como o telejornalismo foi marcado por interesses comerciais das emissoras que detinham ou não os direitos de transmissão dos jogos.
\end{abstract}

Palavras-chave: telejornalismo; enquadramento; jogos olímpicos; futebol masculino

\footnotetext{
1 Doutorando em Educação Física na Universidade Federal do Paraná (UFPR). Mestre em Educação pela Universidade Federal de Santa Catarina (UFSC) (2012). Licenciado em Educação Física pela Universidade do Vale do Itajaí (UNIVALI) (2009). Institución: UFPR Universidade Federal do Paraná - Brasil. E-mail: antonioluisf@gmail.com

2 Mestre em Educação Fìsica pela Universidadde Federal de Santa Catarina (UFSC). Professor na rede municipal de ensino de CamboriúSC. E-mail: bc.leandro@gmail.com

3 Mestre em Educação pela Universidade do Vale do Itajaí (UNIVALI). Professor na Universidade Regional de Blumenau (FURB) e na rede municipal de ensino de Itajai/SC. Institución: FURB - Professor na Universidade Regional de Blumenau. E-mail: heitorluizfurtado@hotmail. com

4 Graduando em Educação Física Licenciatura na Universidade Federal de Santa Catarina (UFSC). Institución: UFSC - Universidade Federal de Santa Catarina. E-mail: josimarlottermann@gmail.com

5 Universidade Federal de Santa Catarina (UFSC). E-mail: delorenzi57@gmail.com
} 


\section{Abstract}

This article is the product of an investigation that aimed to analyze the Jornal da Record (JR), Jornal da Band (JB) and Jornal Nacional (JN - Globo) news programs by comparing the framing of their journalistic discourses in the coverage of the men's soccer tournament at the 2012 London Olympics. We followed the reports from July 26 to August 11, 2012. The theoretical-methodological basis of the study was the Frame Analysis based on the mirror theory of Erving Goffman's symbolic interactionism and a rereading of journalism by Tuchman. The research resulted in the definition of five categories, which are developed in this article: a) television rights and journalistic coverage, b) non-programming, c) nationalism, d) personification, and d) infotainment. The analysis concludes that television news shows how television journalism was marked by the commercial interests of the television networks that had (or did not have) the Olympics broadcasting rights.

Keywords: television journalism; framing; Olympic Games; men's soccer

\section{Resumen}

El presente artículo es producto de una investigación que tuvo como objetivo analizar los telediarios Jornal da Record (JR), Jornal da Band (JB) y Jornal Nacional (JN - Globo) comparando los encuadres de sus discursos periodísticos en la cobertura del torneo de fútbol masculino dentro de los Juegos Olímpicos de Londres en 2012. Se siguieron estos noticieros en el periodo del 26 de julio al 11 de agosto de 2012. La base teórico-metodológica del estudio fue la teoría del encuadre (frame analysis) fundamentada en la teoría del espejo del interaccionismo simbólico de Erving Goffman y en una relectura, para el periodismo, hecha por Tuchman. La investigación dio como resultado la identificación de cinco categorías, las cuales se desarrollan en este artículo; estas categorías son: a) los derechos de televisión y la cobertura periodística, b) la no programación, c) el nacionalismo, d) la personificación y d) el infoentretenimiento. El análisis concluye que los telediarios muestran cómo el periodismo televisivo fue marcado por intereses comerciales de las cadenas televisivas que tenían o no los derechos de transmisión de los juegos.

Palabras clave: periodismo televisivo; encuadre; juegos olímpicos; fútbol masculino

Fecha de recepción: 27 de mayo de 2016

Fecha de aprobación: 5 de febrero de 2017

Para citar este artículo:

Bianchini, L., Fermino, A., Furtado, H., Lotterman J. y Pires, G. (2017). Futebol masculino nos Jogos Olímpicos de Londres/2012: enquadramentos de alguns telejornais brasileiros. Lúdica Pedagógica, (25), 117-126 


\section{INTRODUÇÃO}

Pela primeira vez em muitos anos, uma edição dos Jogos Olímpicos (Londres/2012) não seria televisionada em sinal aberto para o Brasil pela Rede Globo de Televisão, mas pela Rede Record. Aos pesquisadores da mídia esportiva, $\mathrm{o}$ fato se apresentava como uma oportunidade ímpar para se observar as relações entre informação e entretenimento, na hipótese de que poderia haver impactos no telejornalismo esportivo das duas emissoras, influenciados pelo setor do entretenimento (e publicitário) da que detinha ou não os direitos televisivos de transmissão. Para não se configurar como uma mera "troca de sinais" entre Globo e Record, a Bandeirantes foi tomada como "testemunha". Nesse sentido, visamos analisar como as três emissoras de televisão aberta tratariam jornalisticamente os Jogos Olímpicos de Londres 2012 (J0/2012).

Estudos sobre o tema tem demonstrado que as fronteiras entre o jornalismo, o entretenimento e a publicidade, tripé que constitui o discurso midiático clássico, tornamse cada vez mais flexíveis, implicando questionamentos sobre a confiabilidade das informações veiculadas pela mídia (Pires, 2002; Gurgel, 2012). Para Gurgel (2012, p. 11), o telejornalismo esportivo é um dos campos em que tal fato se mostra mais evidente: "ele se confunde, frequentemente, com puro entretenimento".

Como base teórico-metodológica, nos valemos da Análise de Enquadramento (frame analysis), fundamentada na teoria do espelho oriunda do interacionismo simbólico de Erving Goffman e em uma releitura, para o jornalismo, feita por Tuchman (Traquinas, 2001). Para Entman (1994, como citado em Mesquita, 2011), enquadrar é selecionar alguns aspectos de uma realidade e fazê-los mais destacados em uma narrativa midiática, de maneira a promover uma visão particular da questão e propor interpretações ou avaliações morais sobre ela. Carvalho (2000, como citado em Antunes, 2009) referese aos frames como formas ligadas à estruturação do discurso, como pano de fundo que, a partir de elementos postos em evidência (ou obscurecidos), propõe uma interpretação dos textos midiáticos. Também podemos compreender o conceito desde a clássica metáfora da mídia como uma "janela para o mundo":

As pessoas apenas enxergam o mundo através da moldura de uma janela. Se a moldura da janela é muito pequena, as pessoas só enxergarão uma pequena parte do mundo. Se a janela na parede é voltada para o oeste, as pessoas apenas enxergarão o oeste [...]. Em outras palavras, a mídia pode mostrar apenas uma pequena parte do mundo a partir de um particular ponto de vista. (Park, 2003, como citado em Leal, 2007, p. 1).

Assim, o objetivo da pesquisa foi analisar os principais telejornais das emissoras selecionadas - Jornal da Record (JR), Jornal da Band (JB) e Jornal Nacional (JN Globo) ${ }^{6}$, visando comparar os enquadramentos dos seus discursos jornalísticos na cobertura dos JO/2012. Cabe ressaltar, que a escolha por analisar esses três noticiários televisivos se deu de acordo com os seguintes motivos: 1) Como mencionado anteriormente, pela primeira vez a emissora televisiva de canal aberto Record foi a detentora dos direitos de transmissão dos Jogos Olímpicos de Londres/2012. 2) Estes três noticiários televisivos são os principais programas jornalísticos em canal aberto do país, sendo transmitidos em horário nobre, ou seja, após as $19 \mathrm{~h} 30 \mathrm{~min}$. O período de observação foi o da realização do evento (25/7 a 11/8/2012). Os telejornais foram recolhidos e assistidos, resultando dessa pré-análise a escolha pelo torneio olímpico do futebol masculino, que se justifica por tratar-se de um esporte com significativa identificação com a cultura brasileira e também, por ser a única medalha olímpica ainda não conquistada pelo "País do Futebol". Em uma análise do conteúdo (Bardin, 2009) do material recolhido, foi possível identificar cinco categorias temáticas, apresentadas e discutidas a seguir.

\section{DIREITOS TELEVISIVOS E COBERTURA JORNALÍSTICA: IMPACTOS, (IN) DEPENDÊNCIA?}

Para o telespectador brasileiro, a cobertura dos JO/2012 trazia como novidade os direitos de transmissão como produto exclusivo da TV Record. Ainda que os direitos televisivos se refiram apenas à transmissão das competições, ligando-se, portanto, ao gênero entretenimento, entendíamos que isso poderia produzir efeitos no campo jornalístico das emissoras. Nesse sentido, cabiam alguns questionamentos: quanto à informação, que

6 Jornal da Record -. Mais informações: http://noticias.r7.com/ jornal-da-record/conheca-a-equipe-que-faz-o-jornal-da-record-23032016; Jornal da Band . Mais informações: http://noticias.band.uol.com.br/jornaldaband. Jornal Nacional. Mais informações em: http://g1.globo.com/jornal-nacional/. 
impacto isso poderia desencadear? 0 fato da Record ter a exclusividade dos J0/2012 ampliaria o foco e a extensão do seu jornalismo? Haveria limitações ao telejornalismo das demais emissoras?

Introduzindo a discussão, apresentamos os dados de tempo de cobertura sobre o tema futebol masculino nos telejornais e dias selecionados:

Quadro 1: tempo das matérias sobre futebol masculino por telejornal

\begin{tabular}{|c|c|c|c|}
\hline $\begin{array}{c}\text { Telejornal } \\
\text { Data }^{1}\end{array}$ & JR & JB & JN \\
\hline $26 / 7$ & $7 \mathrm{~min}$. & $30 \mathrm{seg}$. & $45 \mathrm{seg}$. \\
\hline $27 / 7$ & $2 \mathrm{~min}$. & - & - \\
\hline $28 / 7$ & $3,5 \mathrm{~min}$. & - & - \\
\hline $31 / 7$ & $4 \mathrm{~min}$. & - & $10 \mathrm{seg}$. \\
\hline $06 / 8$ & $8 \mathrm{~min}$. & - & - \\
\hline $07 / 8$ & 9,5 min. & $40 \mathrm{seg}$. & $20 \mathrm{seg}$. \\
\hline $10 / 8$ & $15 \mathrm{~min}$. & $30 \mathrm{seg}$. & - \\
\hline $11 / 8$ & $10 \mathrm{~min}$. & $30 \mathrm{seg}$. & $1 \mathrm{~min} .20 \mathrm{seg}$ \\
\hline Tempo total & 59 minutos & $\begin{array}{r}2 \text { min. e } \\
10 \mathrm{seg} .\end{array}$ & $\begin{array}{r}2 \text { min. e } \\
35 \text { seg. }\end{array}$ \\
\hline
\end{tabular}

Fonte: produzido pelos autores

0 quadro 01 permite constatarmos grande diferença de tempo de reportagens dedicadas à cobertura do futebol masculino nos telejornais das três emissoras. No JR, foram constatadas notícias sobre o tema nos 8 dias analisados, com quase uma hora (59 minutos), média diária de $07 \mathrm{~min}$. e $37 \mathrm{seg}$. As outras emissoras deram destaque em apenas metade dos dias observados (4 dias em 8) e o tempo também foi semelhante: no JB, $02 \mathrm{~min}$. 10 seg., média de 32,5 seg. nos 4 dias; no JN, 02 min. e 35seg. ou 37,5 seg. diários.

Diante disso, podemos considerar que o princípio norteador da imprensa livre, baseado na independência do jornalismo em relação aos interesses comerciais das empresas de comunicação, parece não se aplicar a este caso. Ficou evidente que o fato de a Record possuir os direitos de transmissão dos J0/2012 e, assim, poder captar patrocinadores e anunciantes interessados em associar suas marcas ao "produto" olímpico, pode ter relação com o fato de o seu telejornalismo ter sido alargado, destinando quase 25 vezes mais tempo do que as suas duas concorrentes dedicaram em seus telejornais. Neste contexto, é lícito considerar as alternativas: ou a Record "inflou" em seu telejornalismo um tema sobre o qual detinha exclusividade como produto de entretenimento; ou Band e Globo restringiram as informações relacionadas ao futebol masculino porque não lhes interessava repercutir jornalisticamente um produto comercial explorado com exclusividade pela concorrente. Ou talvez seja mais razoável admitirmos que as duas alternativas podem ser verdadeiras.

Marcondes Filho (1989), em 0 Capital da Notícia, discute o caráter de mercadoria que a informação assume na contemporaneidade. Como os demais bens da sociedade capitalista, a notícia pode ser tematizada a partir da dupla dimensão da mercadoria: o valor de uso e o valor de troca. Para cumprir seu papel comercial e venderse, a informação, matéria prima do jornalismo, precisa ser construída em forma de notícia de modo a seduzir o consumidor (leitor, ouvinte, telespectador). Há, no entanto, um "segundo cliente" do editor da notícia: o mercado publicitário.

Ele [o editor] colocará sua mercadoria, então, em dois diferentes mercados que na verdade não passam de um só: o comprador do espaço publicitário estará visando ao mesmo público, à faixa de leitores de jornal à qual ele pretende ter acesso. (Marcondes Filho, 1989, p. 26).

Neste sentido, na produção da notícia são empregadas estratégias - enquadramentos - que não apenas capturem a atenção do receptor sobre o conteúdo que veicula, mas o induza a querer mais, a aguardar ou procurar por informações complementares ou mais atualizadas, percurso no qual o receptor poderá ter contato e seduzir-se pelo material publicitário.

No caso em estudo, para contemplar a dimensão publicitária do mercado, a Record usou seu jornalismo para "mercadorizar" o produto de entretenimento que dispunha com exclusividade. 0 seu jornalismo teve o objetivo de informar, mas também o de convencer o telespectador a querer saber mais, mesmo que isso não passe de matérias de interesse do público (curiosidade) e não de interesse público (importância social) ${ }^{7}$, e que sirva apenas para garantir audiência à transmissão dos J0/2012.

Já a estratégia das outras emissoras, ao silenciarem sobre um fato esportivo mundial, segue a mesma lógica, apenas com sinais inversos: sacrificar a informação para não "vender" o produto da concorrente, o que se configura igualmente como um procedimento jornalístico criticável. É preciso reconhecer que, para a sociedade do

\footnotetext{
7 Para saber mais sobre os conceitos de interesse público e interesse do público, ver Vidal (2010).
} 
"País do Futebol", era do interesse público acompanhar a participação da sua seleção olímpica. A invisibilidade promovida por Band e Globo nada mais foi do que uma estratégia empresarial, eticamente questionável, que se imiscuiu no telejornalismo.

\section{NÃO AGENDAMENTO PARA A CONCORRÊNCIA: A INFORMAÇÃO SACRIFICADA}

Os megaeventos implicam uma grande mobilização de investimentos em infraestrutura, mobilidade urbana, política, marketing, entre outros meios que cercam o evento. Assim, próximos de sediar um megaevento, é possível observar uma avalanche de informações que divulgam, dão ênfase e antecipam os grandes eventos esportivos.

Este processo é denominado de agendamento, uma tentativa de inserir na agenda social temas ou fatos vindouros que são do interesse de grupos com o poder de influenciar a opinião pública. Neste sentido, "o agendamento, portanto, é sempre exercido pela mídia, veículo que opera tais interesses, mas tem uma relação de interação com a opinião pública, assim como com grupos privados ou da esfera pública" (Mezarroba; Messa \& Pires, 2011, p. 37).

Este mesmo princípio também pode ser observado no sentido contrário, isto é, quando o não agendamento é uma estratégia de enquadramento, pois ambas partem do mesmo ponto de interesses. Assim, veiculam a informação que caracterizam como mais importante no lugar de outras e estas escolhas direcionam o olhar dos telespectadores, oferecendo a eles apenas uma pequena parcela da paisagem, caracterizando-se a noção de priming, trazida por Rothberg (2010, p. 55), em que, "as mídias preparariam o campo das ideias, presumivelmente no ponto em que elas tendem a ser compartilhadas por certas camadas de receptores, de maneira a torná-lo mais propício ao florescimento de certas visões dos fatos e processos políticos, e não outras".

Tais estratégias foram observadas no telejornalismo das três emissoras acompanhadas. Enquanto o JR anunciava as disputas que transmitiria nos dias seguintes, sobretudo envolvendo atletas ou equipes brasileiras, os telejornais JN e JB praticaram o não-agendamento. Por não deterem os direitos de transmissão dos J0/2012, optaram por dar mínimo espaço de cobertura do evento, como se viu (Quadro 1). Esta estratégia que objetivava não dar visibilidade ao produto da concorrente foi ainda mais evidente na medida em que esses telejornais, nas poucas pautas sobre o futebol olímpico que fizeram, só noticiavam fatos já ocorridos, como os resultados oficiais, sem nunca informar quais seriam os desdobramentos, as próximas partidas, nem quando elas ocorreriam. Tratou-se, claramente, de uma opção para evitar o agendamento da programação que só a concorrente dispunha para oferecer à audiência. Esse não-agendamento pode ser considerado uma estratégia de enquadramento, como afirma Cunha (2004, p.1): "[...] a omissão de um fato, negligenciado da cobertura ou que tenha um destaque ínfimo, também é um tipo de enquadramento. Minimizar o espaço - físico no caso da imprensa e temporal no caso da televisão - constitui uma estratégia da mídia na cobertura dos fatos".

Tomemos como exemplo o jogo da seleção brasileira contra a Coreia do Sul, pelas semifinais do torneio olímpico masculino. 0 JR, no dia 6 de agosto de 2012, apresentou uma reportagem da seleção brasileira, sobre a escalação de Mano Menezes, estatísticas de gols e preocupação com a defesa, entre outras questões, que levaram a reportagem a computar 8 minutos com informações sobre a seleção brasileira, que jogaria no dia seguinte. Por outro lado, tanto no JN quanto no JB, as informações sobre o jogo do dia seguinte foram completamente ignoradas. 0 resultado do jogo é mencionado pelas duas emissoras no dia 7 de agosto de 2012, com apenas 40 segundos por parte do JB e 20 segundos pelo JN. Muito diferente, novamente, do que apresentou o JR, com 9,5 minutos de reportagem sobre a seleção brasileira. Assim, o não-agendamento por parte das emissoras não detentoras dos J0/ 2012 se configura como um enquadramento que as emissoras utilizaram para não despertar a atenção do telespectador para o evento. Isso porque:

Os enquadramentos tornam algumas ideias mais enfáticas e outras aparentemente inexistentes, sem nenhuma importância; ou seja, determinadas informações são mais discerníveis e memoráveis que outras, dependendo do enquadramento dado à notícia (Cunha, 2004, p. 01).

É possível constatar uma diferença substancial no grau de importância dado (enquadramento) ao evento pelas 
demais emissoras, com um interesse muito baixo pelo assunto, ou mesmo nenhum interesse, como o caso do JN que não apresentou reportagens sobre a final olímpica a ser realizada no dia seguinte.

Entendendo, com Reis (2009), que a informação é um direito do cidadão, devemos destacar que tais informações foram negadas, por parte da rede Globo de Televisão e da Bandeirantes, como clara decisão editorial de restringir o acesso dos telespectadores às informações disponíveis sobre o evento. Mesmo levando em consideração que o resultado final após o jogo foi divulgado por ambas redes de canal aberto, é necessário criticar que tais informações ao longo do evento foram esquecidas, porque o que estava em jogo não era apenas a informação mas também a possibilidade de aumentar a audiência da emissora concorrente.

\section{O NACIONALISMO NA RECORD: O BRASIL É “NOSSO”}

Giulianotti (2002) sustenta que com a globalização que chegou também ao futebol uma nova classe de torcedores começa a frequentar os estádios. Seriam espectadores, em vez de torcedores, portanto mais contidos e não tão apaixonados por seus clubes, o que diminuiria o tom nacionalista deste "pós-torcedor". Todavia, para Escher e Reis (2008, p. 43), que fazem uma análise desse conceito, a suposta nova classe de torcedor "parece ainda não ser a totalidade dos torcedores que acompanham o futebol, principalmente quando tratamos do futebol brasileiro", pois no Brasil o nacionalismo relacionado com o futebol ainda é muito presente, tanto em relação aos clubes tradicionais, quanto (e sobretudo) quando a seleção nacional está em campo.

Uma das características que marca as jornadas esportivas na Globo (sobretudo quando narradas por Galvão Bueno) é o enfoque emocional e nacionalista alguns tons acima do razoável ${ }^{8}$. 0 próprio jornalista ${ }^{9}$ se apresenta como um vendedor de emoções ao transmitir eventos esportivos, especialmente quando o Brasil está envolvido.

8 Para melhor entendimento, estamos considerando como nacionalismo um tom exacerbado nas expectativas, nos desempenhos e nas repercussões dos atletas brasileiros, enquadramento que beira o ufanismo quando as narrativas televisivas teimam em discordar dos fatos, apostando numa leitura ingênua do receptor.

9 Entrevista a Veja, edição 2178, n 33, 18/8/ 2010. Disponível em: http://veja.abril.com.br/acervodigital/home.aspx
A partir de 2010, a Rede Record passa ser a detentora dos direitos dos eventos olímpicos, num pacote que incluía Olimpíadas de Inverno de 2010, os Panamericanos de 2011 e os Jogos Olímpicos/Paralímpicos de 2012. Logo na primeira experiência na transmissão exclusiva dos megaeventos, os Jogos Panamericanos de Guadalajara no México, o que marcou a cobertura da Record, além de uma série de erros técnicos, foi a elevação do tom nacionalista da abordagem, antes criticado na Globo, a ponto desse tema ter virado mais um ingrediente na disputa entre as duas emissoras. $\mathrm{Na}$ transmissão exclusiva dos J0/Londres, percebeu-se uma melhora significativa da qualidade técnica e operacional da Record, mas o discurso altamente nacionalista e até mesmo ufanista manteve-se presente na cobertura da participação brasileira.

No JR, pode-se constar, por diversas vezes, o uso de frases que expressam muito mais uma posição de torcedor do que de jornalista:

\begin{abstract}
"Boa noite Brasil. Falamos ao vivo direto de Londres e o futebol brasileiro estreou com vitória nas olimpíadas. Um jogo que começou com um show de bola e terminou com sufoco." (Apresentadora do JR, falando da estreia da seleção brasileira nas Olimpíadas).

“Olá, boa noite Brasil. 0 jornal da Record está no ar e começa com a bela vitória da seleção brasileira de futebol, três a zero em cima da Correia. Estamos na final olímpica e agora só falta um jogo, um joguinho pra tão sonhada medalha para o futebol brasileiro" (Apresentadora do JR, falando da vitória da seleção brasileira sobre a Correia do Sul, que garantiu vaga para a disputa da final Olímpica).
\end{abstract}

Estes são alguns exemplos que ocorreram nas reportagens do JR, evidenciando o discurso nacionalista adotado pela emissora. Fato este que não foi observado nas outras duas emissoras analisadas, que tratavam da seleção brasileira com neutralidade e formalismo, como nos exemplos abaixo:

"Hoje foi a vez dos homens estrearem no futebol" (Apresentador do JB iniciando a reportagem que mostra o primeiro jogo da seleção brasileira).

"A seleção brasileira de Mano Menezes estreou com vitória hoje nos Jogos Olímpicos de Londres" (Apresentadora do JN, falando sobre o primeiro jogo da seleção nas Olimpíadas). 
Essa diferença de tratamento causa repercussões sobre as representações que são produzidas e compartilhadas socialmente:

Os produtos veiculados pela mídia utilizam linguagens e articulam significados a determinados referentes, criando representações que, ao serem veiculadas para a sociedade, tomada como "massa", ressaltam alguns significados, ocultam outros, incorporam significados correntes em alguns grupos e os ampliam para toda a sociedade, entre outras operações, nas quais se manifesta o potencial de veiculação de ideologia através da mídia (Gastaldo, 2009, p. 355).

Da mesma forma, a mídia se utiliza dessas habilidades para vender o produto que tem disponível. Neste caso, a Record tinha como produto os Jogos Olímpicos. Estas habilidades, por sua vez, podem muitas vezes não demonstrar o verdadeiro produto, ou ainda, difundir a visão que é de maior interesse da mídia. Neste sentido, percebemos que o jornalismo da Record fez uso do futebol, esporte que é bastante identificado com a sociedade brasileira, como um produto que estava disponível a ela para ser comercializado.

Brüggemann e Pires (2012) descrevem o futebol atual como um esporte totalmente telespetacularizado (Betti, 1998), presente diariamente na pauta midiático-esportiva nacional, porque o futebol atrai um grande número de torcedores/consumidores, por se tratar do esporte hegemônico no país. Na mesma direção, Gastaldo descreve como é o produto midiático futebol relacionado com um megaevento esportivo:

0 interesse social pelo futebol no Brasil durante a Copa é apropriado pela mídia, que, em princípio, atende a uma "demanda social" pré-existente, produzindo peças de comunicação e criando um circuito de produção e consumo motivado pelo evento em curso, no qual se inserem, além da cobertura dos jogos, cadernos especiais nos jornais e revistas, longas matérias nos telejornais, programas diversos com a temática da Copa, anúncios publicitários, etc, colaborando de modo ativo para definir a realidade nos termos ideológicos da representação do Brasil como "o país do futebol". (Gastaldo, 2009, p. 362).

Podemos dizer que isto, igualmente, ocorreu com o futebol dos J0/2012, não na mesma proporção da Copa do Mundo, mas que também se tornou um grande produto, principalmente pela expectativa de que a tão sonhada medalha de ouro olímpica pudesse ser conquistada, fazendo crescer o nacionalismo na cobertura e no telejornalismo.

Por fim, mesmo após a derrota para México na partida final, em que a sonhada medalha de ouro não veio, o discurso nacionalista apresentado no JR manteve-se presente. Expressões como "nossa seleção", "nosso sonho de medalha" continuaram sendo utilizadas nas reportagens sobre a derrota no jogo final. A apresentadora do JR assim se referiu: "O desafio da medalha de ouro ficou para as Olimpíadas do Rio em 2016". Aliás, frase que mostra que a Record já aproveitou para agendar a próxima Olimpíada, a ser realizada no Rio de Janeiro, numa alusão à categoria "presente perpétuo", já identificada em estudos de análise de cobertura midiático-esportiva (Pires et al., 2010; Mezzaroba et al., 2009).

\section{A PERSONIFICAÇÃO DA NOTÍCIA NO ESPORTE}

A personificação da notícia no campo esportivo passa inicialmente pela compreensão de que, no mundo de hoje, só alcança visibilidade aquilo que é veiculado pelos meios de comunicação; da mesma forma, a não presença parece dar indício da não existência de tal fenômeno (Lemos, 2002). Para a autora, a personificação é a síntese dos fatos centrada em figuras singulares que simplificam a complexidade do real. 0 recurso à personificação oferece dois resultados principais: é econômico, pois simplifica a exposição e a compreensão de um determinado fenômeno; e permite ao leitor ou telespectador estabelecer laços afetivos com o personagem criado.

Como se sabe, o futebol ocupa um lugar de destaque na cultura do país, extrapolando a dimensão esportiva para vincular-se à formação sociocultural da sociedade brasileira (Ferraz \& Marques 2012). Ídolos esportivos extrapolam esse âmbito, passando a fazer parte do cotidiano do público, graças à construção da sua imagem social pela mídia e, mais recentemente, pelas redes sociais.

$\mathrm{Na}$ analise procedida, referente ao futebol, um esporte coletivo, foi possível perceber, uma vez mais, a personificação da notícia, através da presença marcante da construção do ídolo esportivo. 0 exemplo disso foi o 
lugar de destaque de Neymar nas coberturas jornalísticas, principalmente da Record, a detentora dos direitos televisivos dos jogos, mas também nas demais emissoras.

A presença marcante do atacante nos telejornais da Record é comprovada pelas inúmeras matérias sobre o atacante. Tomemos como exemplo, a reportagem que ilustra a personificação da notícia que foi exibida em 07/08 no JR, em reportagem do jogo do Brasil contra a Coreia do Sul, com ênfase no comportamento de Neymar durante todo o jogo. Segundo os repórteres, os olhos do mundo estão voltados para o atacante e, mesmo que Leandro Damião fosse o artilheiro da competição, todo credito é dado a Neymar. Por fim, o repórter sentencia: "aos vinte anos, Neymar já tem história no futebol, conquistando títulos pelo Santos, fez fama mundial, fortuna, mas agora ele tem pela frente o jogo mais importante da carreira. Nessa final de olimpíadas, ele pode se consagrar como um herói nacional".

A análise da afirmação do repórter da Record oferece indícios de como a emissora pautou sua cobertura jornalística sobre a figura do ídolo. Um enquadramento intrigante e digno de maiores reflexões, tais discursos enfocam aquilo que Lemos (2002) salientou sobre os discursos midiáticos, na criação de personagens que remontam a verdadeiros heróis contemporâneos.

Para Helal (2003), existe uma diferença entre herói e celebridade. Enquanto essa pode viver para si, os heróis precisam devolver algo à sociedade. A figura de Neymar, tão exposta durante os jogos, remonta à construção de um herói (acima de celebridades) pela mídia brasileira. Seu retorno à sociedade brasileira seria a reconstrução daquilo que usualmente chamamos de futebol-arte e de que tanto nos jactamos. Seu jeito divertido, alegre, seus inúmeros penteados, seus dribles, seu jeito irreverente de ser, são fatores sedutores e apropriados para a construção de um ídolo/herói nacional. Ferraz e Marques (2012) consideram que Neymar carrega consigo toda a "brasilidade", marca da prática do futebol nacional que busca na ginga, no drible, no lúdico, as formas de aumentar e realçar alegremente esse esporte.

Desta forma, a despeito de participar de uma modalidade esportiva coletiva, Neymar surge como protagonista brasileiro tanto por aliar as paixões enraizadas na cultura futebolística brasileira, quanto por atender as demandas do espetáculo midiático contemporâneo.
Um ídolo/herói agradável e inovador, de estilo e visual diferenciados, que cria moda e dita tendências, que através da mídia propõe um modelo de como as pessoas devem se comportar e se apresentar (Ferraz \& Marques 2012).

Ao pautar o seu modo de jogar e as influências que o jogador traz para a sociedade, os meios de comunicação conseguem aproximar a vida do atleta ao cotidiano da população. Configura-se assim, nessa personificação, a figura de um ídolo nacional, que é uma necessidade constitutiva do discurso midiático - esportivo.

\section{INFOTENIMENTO NA MÍDIA ESPORTIVA: ENTRE A INFORMAÇÃO E O ENTRETENIMENTO}

As fronteiras de gênero que historicamente eram estabelecidas pelo discurso midiático, entre informação, entretenimento e publicidade, vão sendo aos poucos derrubadas. Percebe-se que hoje existe uma crescente ambiguidade entre informação e entretenimento, caracterizando-se como um fenômeno midiático que ilustra o conceito de infotainment ou infotenimento, conforme a expressão tem sido traduzida para o português (Gomes, 2008). Para a autora, não deveríamos evidenciar o infotainment apenas como negativo, pois percebido à luz das transformações culturais que vivenciamos, esse fenômeno evidencia o caráter de processo histórico e cultural do jornalismo, colocando o prazer de forma legitima como parte dos propósitos jornalísticos, consequentemente concebendo o entretenimento como já pertencente da história do jornalismo. Nesse sentido, o jornalismo esportivo é uma dimensão que vem se aproximando do entretenimento, talvez buscando uma renovação.

No que se refere à mídia televisiva esportiva brasileira, o infotenimento pode ser ilustrado pela "leifertização", expressão utilizada por críticos do meio jornalístico, como o jornalista Juca Kfouri, em referência ao enquadramento quase performático de Thiago Leifert, então apresentador esportivo da Globo. Segundo a crítica de Kfouri (2013), "o jornalista pode ser engraçado, bem-humorado, mas não pode esquecer seu papel na sociedade. A programação esportiva da TV aberta se apalhaçou e quase não tem, rigorosamente, nada de importante".

O jornalista Anderson Gurgel também concorda com tal associação: 
[...] ele [o jornalismo esportivo] se confunde, frequentemente, com puro entretenimento. Isto, por seu lado, propicia [...] e o envolvimento com outras atividades incompatíveis com a prática do jornalismo, como agenciamento de publicidade, marketing e política privada dos clubes, federações, confederações e empresas. (Gurgel, 2012, p. 11).

A aproximação entre o esporte e a mídia decorre do fato que "o esporte como espetáculo gera um 'show de imagens', que é ingrediente perfeito para o entretenimento na sociedade contemporânea." (Gurgel, 2012, p. 8). Essa foi uma estratégia de enquadramento amplamente empregada pelo telejornalismo do JR, com óbvios interesses comerciais. Por exemplo, Neymar foi tema de várias pautas na programação jornalística da Record durante a cobertura dos J0/2012, em matérias sobre seus familiares, seus penteados, o fervor das suas fãs, replays de suas jogadas com fundo sonoro que dramatizava o show, puro infotenimento. Pato também teve pautas assim, em que $o$ assunto transitou sobre as tietes e suas relações amorosas com mulheres famosas. Esses assuntos somente atendem aos "interesses do público" específico que, de certo modo, não são necessariamente entusiastas do futebol.

Já nos telejornais das outras duas emissoras isso não ocorreu, ficando evidente que elas, por não terem o direito de transmissão, fizeram uma cobertura jornalística "neutra", divulgando somente informações de forma objetiva e pontual, procurando veicular apenas o mínimo necessário para que não ficasse evidente a sonegação das informações. Com esse enquadramento, as emissoras pretenderam fazer com que o jornalismo contribuísse para não entreter o telespectador e tampouco agendasse os eventos do J0/2012, produto que não as pertencia.

\section{CONSIDERAÇÕES FINAIS}

O estudo teve por objetivo identificar e analisar os enquadramentos promovidos pelos telejornais de emissoras de sinal aberto no torneio de futebol masculino dos J0/2012. Nossa variável de comparação era o fato de que uma emissora, a Record, detinha os direitos televisivos para transmissão exclusiva dos Jogos, enquanto as outras, Globo e Bandeirantes, não os possuíam. Decorrente desse fato, a questão guia era saber se a programação exclusiva pertencente ao gênero entretenimento e afeito à área comercial, implicaria consequências para os modos de abordagem no telejornalismo das emissoras.

As evidências discutidas nas cinco categorias de análise demonstram com clareza uma associação direta entre o telejornalismo e o produto comercial de entretenimento. A diversidade dos enquadramentos procedidos pelos três telejornais, em relação às informações sobre a participação da seleção brasileira olímpica de futebol, expressa tanto quantitativa quanto qualitativamente que a esfera jornalística foi refém dos interesses comerciais das emissoras. De um lado, a detentora dos direitos de transmissão transformou seu principal telejornal (JR) em um espaço de divulgação do seu produto comercial exclusivo, dando carona aos interesses de seus anunciantes. Também Globo e Bandeirantes não tiveram pruridos éticos ao quase ignorarem a participação da seleção brasileira de futebol nos J0/2012, evitando divulgar o produto da concorrente e assim ampliar sua audiência.

Além do auto-agendamento no telejornalismo como estratégia de divulgar sua programação comercial exclusiva, vimos que a Record optou pelo infotenimento, procurando dar um sentido leve e bem-humorado à pauta do seu jornalismo, retirando qualquer perspectiva de reflexão e valendo-se de situações curiosas como se informações fossem. Foi possível perceber ainda que o JR recorreu a enquadramentos que passaram pelo apelo emocional ao nacionalismo e à identificação do povo brasileiro com a sua seleção de futebol; também se utilizou da estratégia de personalizar a informação, elegendo Neymar como o personagem-ídolo que simplifica e individualiza a autoria coletiva de feitos memoráveis e complexos.

Pelos achados da pesquisa, acreditamos que estudos como esse podem contribuir para enriquecer o campo sociocultural da Educação Física, fornecendo aos profissionais da área um quadro detalhado sobre como o esporte, um dos seus principais temas de estudo e de intervenção, é enquadrado pelo telejornalismo esportivo. Essas decisões editoriais da mídia influenciam na produção e consolidação de representações que são socialmente compartilhadas, com possíveis reflexos na forma como crianças e jovens constroem e vivenciam sua cultura esportiva, o que implica responsabilidades pedagógicas para o professor de Educação Física. 


\section{REFERÊNCIAS}

Antunes, E. (2009). Enquadramento: considerações em torno de perspectivas temporais para a notícia. Galáxia, 18, 85-99.

Bardin, L. (2009) Análise de conteúdo. (2 ed.). Lisboa: Edições 70.

Betti, M. (1998). A janela de vidro: esporte, televisão e educação física. Campinas: Papirus.

Brüggemann, A. L. ePires, G. L. (2012). Uma nova imagem/ identidade para a seleção brasileira de futebol: estudo a partir da mídia. Anais do Congresso Sulbrasileiro de Ciências do Esporte. Rio Grande, RS, Brasil, 6.

Cunha, K. M. R. da. (2004). Televisão e política no Brasil. Anales del Congreso Online Del Observatorio para la Cibersociedad. Tecnología e sociedad: a internet como utopia. Barcelona, España, 2. Disponível em http://www.cibersociedad.net/congres2004/grups/ fitxacom_publica2.php?grup=11\&id=444\&idioma=es.

Escher, T.D.A, e Reis, H.H.B. (2008). As relações entre futebol globalização e nacionalismo: o exemplo da Copa do Mundo de 2006. Revista Brasileira de Ciências do Esporte, 30, (1), 41-55.

Ferraz, L. H. M., e Marques, J. C. (2012, setembro). Neymar e sua trajetória espetacular como ídolo nacional. Anais do Congresso Brasileiro de Ciências da Comunicação. Fortaleza,CE, Brasil, 35.

Gastaldo, E. (2009). “O país do futebol” mediatizado: mídia e copa do mundo no Brasil. Sociologias, 11, (22), 352-369.

Giulianotti R. (2002). Sociologia do futebol: dimensões históricas e socioculturais do esporte das multidões. São Paulo: Nova Alexandria.

Gomes, I. M. M. (2008). 0 embaralhamento de fronteiras entre informação e entretenimento e a consideração do jornalismo como processo cultural e histórico. Em: Duarte, E. B.; M. L. Castro. (orgs.). Em torno das mídias: práticas e ambiências. Porto Alegre: Sulina.

Gurgel, A. (2012, setembro) 0 papel do jornalismo nos megaeventos esportivos. Anais do Congresso Brasileiro de Ciências da Comunicação.Fortaleza, CE, Brasil, 35.

Helal, R. (2003). A construção de narrativas de idolatria no futebol brasileiro. Alceu., 4, (7), 19-36.

Kfouri, J. (2013). Seminário de Jornalismo Esportivo (Entrevista com Juca Kfouri) [Arquivo de vídeo]. Disponível em: http://www.youtube.com/ watch?feature=player_embedded\&v=BHVMW1rkspo

Leal, P. M. V. (2007). Jornalismo político brasileiro e a análise do enquadramento noticioso. Anais do
Congresso da Associação Brasileira de Pesquisa em Comunicação e Política.Belo Horizonte, MG, Brasil, 2.

Lemos, C. R. F. (2002). Visibilidade mediada: personalização e promoções na cobertura de futebol. Kinesis, 26, 102-166.

Marcondes Filho, C.(1989). O capital da notícia. São Paulo: Atica.

Mesquita, F. A. (2011). Esporte é (apenas) entretenimento? O lado político e econômico da cobertura midiática ao esporte olímpico brasileiro. Anais do Congresso Brasileiro de Ciências da Comunicação. Recife, PE, Brasil, 34.

Mezzaroba, C. Costa, A. G., Souza, D. M., Ribeiro, S. D., Antunes, S. E., e Hack, C.. (2009). Jogos Pan-Americanos Rio/2007: os "locais" na mídia regional. Descrição e análise da cobertura em jornais das cinco regiões brasileiras. Em: Pires, G. L. (Org.). Observando o Pan Rio/2007 na mídia. Florianópolis: Tribo da Ilha.

Mezzaroba, C., Messa, F. C. e Pires, G. L. (2011). Quadro teórico-conceitual de referência: megaeventos e o agendamento midiático-esportivo. Em: Pires, G. L (Org.). O Brasil na copa, a copa no Brasil (pp, 21-45). Florianópolis: Tribo da Ilha.

Pires, G. L et al. (2010). Jogos Olímpicos e a Dialética Global-Local: os catarinenses em Atenas/2004 na mídia impressa regional. Em: G. Sanfelice.; M. Myskiw. (Orgs.). Mídia e Esporte: temas contemporâneos. Novo Hamburgo: Ed. Feevale.

Pires, G. L. (2002). Educação Física e o discurso midiático: abordagem crítico-emancipatória. Ijuí: Ed. Unijuí.

Reis, S. L. (2009). A regulação pro-concorrencial do setor televisivo - análise do segmento de transmissão esportiva. Dissertação Mestrado em Direito. Universidade Cândido Mendes. Rio de Janeiro. Disponível em: http://www.dominiopublico.gov.br/ download/teste/arqs/cp135135.pdf.

Rothberg, D. (2010). O conceito de enquadramento e sua contribuição à crítica de mídia. Em: Christolofeltti, R. (org.). Vitrine e vidraça: crítica de mídia e qualidade no jornalismo. Covilhã, UBI, LabCom, 2010. Disponível em www.livroslabcom.ubi.pt.

Vidal, D. M. M. (2010). Notícias de interesse público e de interesse do público: a possibilidade de convergência desses interesses. Anais do Congresso de Ciências da Comunicação na Região Centro-Oeste. Goiânia,GO, Brasil, 12. 